\title{
Did Ms Wisdom of Proverbs 8 become a mystery in 4QInstruction?
}

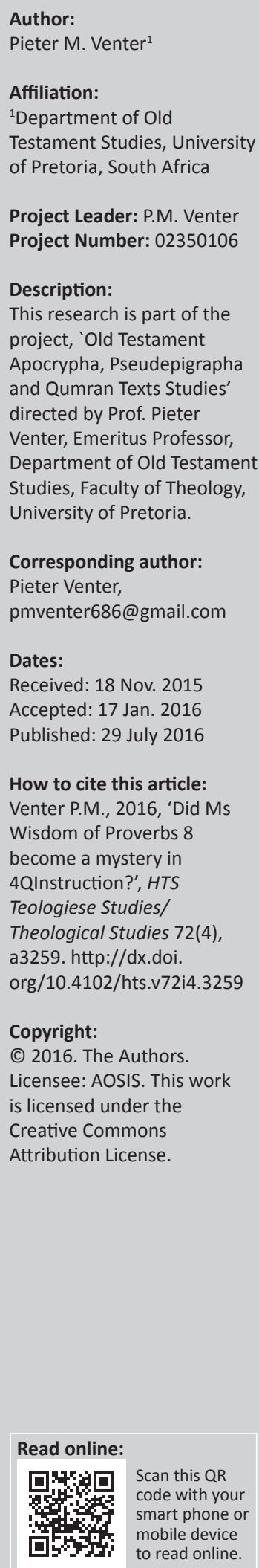

The Hebrew Bible is quoted and alluded to in 4QInstruction. There is an obvious similarity between the way the raz nihyeh of 4QInstruction and Lady Wisdom in Proverbs 8 function. This intertextual study investigates this phenomenon by comparing 4Q416 2 III 8-21 and 4Q417 1 I with Proverbs 8:12-21 and 8:22-31. It is concluded that apocalyptic influence changed the character of Lady Wisdom but not her essential function.

\section{Introduction}

Goff (2013:109) indicates in his commentary on 4QInstruction that words from the fifth ואמכה commandment are presented with key additions in 4Q416 2 III 15-17. To the command to כבוד אביכה (honour your father and your mother) two 'key additions' (Goff 2013:109) are added: במצעדיכה (in your poverty) and lowly state). ${ }^{2}$ By doing this, the Instruction gives to the fifth commandment both a wider field of meaning and 'a theological rationale for filial piety' (Goff 2013:110).

The section of 4Q416 2 III 20-21 deals with marriage. Again, existing biblical literature is amended with 4QInstruction's view on the mebin (learner ${ }^{3}$ ) and his poverty. Both 4Q416 2 column iii line 21 and column iv ${ }^{4}$ '[rely] heavily on Genesis 1-3' (Goff 2013:116). Texts such as Genesis 2:24 and Genesis 3:16 are expounded upon in these sections.

The text of 4Q416, fragment 2 is in form and tone 'like Proverbs 22: 17-24:22, which in turn [is] related to the Egyptian Instruction of Amenemopet and the Aramaic Words of Ahiqar' (Harrington 2001:45).

All of the texts above are linked to other texts. This interconnection is known as intertextuality. The process of intertextuality uses existing texts by either quoting from them (aesthetical production) or by alluding to them, using deconstructionist intertextuality to read the text.

Claes (1987:11) uses the following terms for intertextuality: 'Aesthetical production is when another text is transformed by using techniques such as quoting, paraphrasing, parody or pastiche'. In the case of 4Q416 2 III 15-17 above, the archi text (older, original text) of the fifth commandment is rephrased in the context of another text, like 4QInstruction.

'Allusive' or 'deconstructive re-reading of texts' (cf. Claes 1987:11), on the other hand, is found in texts such as 4Q416 2 III 20-21. Schmitz (1987:25) would call this 'symptomatic intertextuality'. The relationship with Genesis $1-3$ is visible, but no direct indications can be found. As texts are 'dialogical and contingent upon prior discourses' (Goff 2014:216), the relationship can even go further than merely hinting at or citing from other texts. In a new context it can even change and modify the basic elements of another text. ${ }^{5}$ It is not dependent on the older text only, but uses a 'wider web of texts and discourses that are present in the culture in which the composition of texts takes place' (Goff 2014:215). Owing to the polylogical character of texts, they are read in the communication situation not only in relation to other written or oral texts, but in dialogue with the whole surrounding world of phenomena. In her studies Julia Kristeva uses the term intertextualité for this phenomenon.

1.Goff's (2013) numbering of the text of 4 Q Q instruction is followed in this article.

2.Elgvin (1997:78) refers to 4Q423 3 (=1Q26 2), where Leviticus 26:20 is quoted and changed.

3.Elgvin (1997:65) understands the Hebrew mebin as 'the usual designation for the enlightened addressee', the understanding one to whom the mystery has been revealed.

4.The thematic continuation of 4Q416 2 - cf. Goff 2013:114.

5.Goff (2014:223-224) uses Riffaterre's term 'sociolect' (reading a text in a social context) in his study of Ecclesiastes as an intertext of the Dead Sea scrolls. The Biblical book was part of a 'rich web of writings whose language shaped and informed the production of texts in this era' (Goff 2014:223) 
An illustration of intertextualite is found when the role of Lady Wisdom in Proverbs 8 as an agent of wisdom is maintained in 4QInstruction in the form of the raz nihyeh. In 4QInstruction the phrase רז נהיה (the existing secret, the raz nihyeh ${ }^{6}$ ) occurs 23 times (cf. Elgvin 1998:132). Each time it is linked to sapiential instructions analogous to meshalim ${ }^{7}$ (sayings) inter alia found in the biblical book of Proverbs. Not only aesthetic intertextuality with traditional wisdom sayings can be found here, but also deconstructive intertextuality where these types of sayings are linked to the secretive expression of raz nihyeh ${ }^{8}$ giving them a new meaning. Both personified wisdom and the raz nihyeh are linked to a series of instructions. Both function within a spatial and cosmological context mediating knowledge of God's creation. Both operate within the field of wisdom education and introduce the learner to a specific way of life. ${ }^{9}$

Aesthetical intertextuality with Proverbs 8 is also obvious in Ben Sira and 1 Enoch. ${ }^{10}$ The same type of ethical teaching, dealing with issues such as marriage, family relationships and interpersonal relations, is found there. However, Ben Sira equates wisdom directly with the Mosaic Torah (cf. Nickelsburg 2005:171). ${ }^{11}$ First Enoch, especially 1 Enoch 97107 (cf. Nickelsburg 2001:58), links sapiential sayings to an eschatological framework. 4QInstruction links these teachings to the secretive raz nihyeh, but does not have the same apocalyptic agenda as 1 Enoch. ${ }^{12}$ Lady Wisdom's intertextuality with the raz nihyeh, however, is not as obvious as that of Ben Sira and 1 Enoch. To study this less obvious

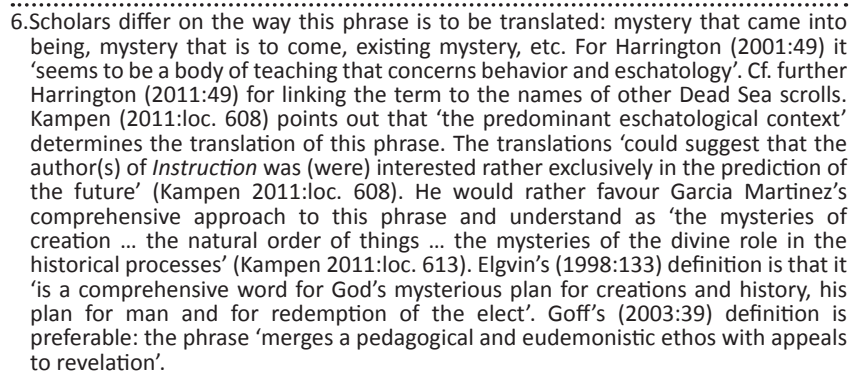
to revelation'.

7.Cf. Goff (2013:12-14) characterising 4QInstruction as a 'Wisdom Text'.

8.Seeing the raz nihyeh as revelation by God, Lockett (2005:143) remarks that 'neither the event of revelation nor its contents is ever described'. It can be either a written document or an 'independent compendium of wisdom' (Lockett 2005:143). It has anyway 'an eschatological frame of reference' (Lockett 2005:143). Elgvin (1998:131) connects the mediative role of the raz nihyeh 'to the study of both biblical and more sectarian books'.

9.Although the date of Proverbs 1-9 is unsure, it is presumed here that it is older than 4QInstruction. Goff (2007:67) posits that 4QInstruction was probably written during the second century B.C.E. Wisdom texts do not have clear allusions to their date of composition.

10.Goff (2007:65) is of the opinion that the relationship between 4 QInstruction and the Qumran community 'is best understood along the lines of 1 Enoch and Jubilees', that supposes one or another form of intertextuality.

11.In her study of Lady Wisdom and Dame Folly, Crawford (1998:357) points out that the figure of wisdom in the apocrypha and pseudepigrapha draws 'heavily on Proverbs 1-9'. In Sira 1:1-20 she is a female figure created before all other things, in Sira 24 she is a divine being and in Sira 51:13-20 she is an 'abstract concept' (Crawford 1998:358). In Wisdom of Solomon 7:22b-8:1 she is an 'eterna emanation of the deity' (Crawford 1998:358). In 1 Enoch 42 she also seeks dwelling among humans like Ben Sira, but is not equated with the Torah like in Ben Sira. A female figure who can be equated to Lady Wisdom is found in 40185. The result of Crawford's (1998:365) investigation is that the development of Lady Wisdom and Crawe Folly in 40184, 185 and 525 ' takes place along lines already discernible in Dam- Fumran literature'. Wisdom non-Qumran literature'. Wisdom lost her separate identity in the growing emphasis 'but occurs broadly in Second Temple literature' (Crawford 1998:365).

12.Elgvin (1998:138, see also 1997:63) even states that the Epistle of Enoch (1 En. $91-108)$ is a 'main source for the compiler of 4 QInstruction'. intertextuality this paper first analyses the character and function of the raz nihyeh in two relevant sections of 4QInstruction. Next, two paragraphs in Proverbs 8 are similarly analysed. These seem to give some information on the probable link between the raz nihyeh and wisdom. The results are then compared in a broader sociological context to answer the question of their probable connection.

\section{Raz Nihyeh in 4QInstruction}

Two sections of 4QInstruction can be studied to investigate the probable intertextuality with wisdom in Proverbs 8: these are 4Q416 2 III $8-21^{13}$ and 4 Q417 1 i. The term raz nihyeh is used in both of these passages, linked to some kind of instruction.

\section{Q416 2 III 8-21}

Goff (2013:94) describes 4Q416 2 III as 'one of the most significant, and best preserved, texts of 4QInstruction' ${ }^{14}$ The main subjects here are 'money and possessions, social relations, and family relations' (Harrington 2001:48). The term raz nihyeh occurs four times in this passage. It is either the object of study (cf. line 14) being equal to examining the truth, or instrumental (cf. the use of the bet instrumentalis) to studying the origins of one's 'glory' (line 9) and of honouring the parents (line 18), or the source (cf. the use of the mem) of his approach to marriage (cf. Goff 2013:115). Every time the secret-to-be is linked to wisdom teaching, expounding to the learner the nature of his elect status and the contents of his filial and matrimonial relationships.

This unit can be subdivided into two sections: 4Q416 2 III $8-15^{15}$ dealing with the nature of the learner's elected status and 4Q416 2 III 15-21' $11^{16}$ addressing his filial and matrimonial relationships (cf. Goff 2013:95).

\section{Q416 2 III 8-15}

This section consists of two subunits: 4Q416 2 III 8-12 and 4Q416 2 III 12-15. The term raz nihyeh occurs in both of these subunits.

In the subunit of 4 Q416 2 III 8-12 the term is used in line 9. Harrington (2001:43) translates it as follows: 'But if they cause you to dwell in splendour, walk in it, and by the mystery that is to be/come study its origins'. In this subunit (8-12) study of the mystery enables the learner to understand the meaning of his inheritance ${ }^{17}$ (cf. Goff 2013:101). Studying the raz nihyeh 'is

13.Preference is given to this passage because it is better preserved than 404171 and therefore provides a larger context for investigation.

14.Cf. also Harrington (2001:44) for the same remark.

15.Goff (2013:100-108) divides this section into three subunits of 4 Q416 2 III 8-15: lines $8-12$ beginning and ending with a vacat dealing with the learner's inheritance and poverty; lines 12-14 encouraging the mebin to learn; lines 14-15 where the mystery is used instrumental to encourage the addressees to learn. I see the resultant line 15 as still part of a second subunit 12-15.

16.Goff $(2013: 109,112,114)$ divides this section into the subunits of $4 Q 4162$ III 1521 of lines $15-17,17-19$ and $20-21$.

17.According to Goff (2003:67), the word 'Inheritance' is a key word in 4QInstruction's deterministic theology. 
the chief means by which the mebin can learn something' (Goff 2013:103). This enigmatic expression is linked in these lines to well-known terms of the Hebrew Bible, giving to them a new meaning. '[C]onventional pieces of advice on social relations' (Harrington 2001:47) receive a new interpretation by linking them to the idea that God has given 'the one being instructed a new and glorious identity' (Harrington 2001:47). Whereas 'inheritance' generally has a monetary meaning, it becomes here an 'inheritance of glory' (lines 11-12) having a worldly as well as a heavenly aspect. As part of God's divine design that guides reality (cf. Goff 2013:102) the learner receives an inheritance that gives to him an elected status on earth, life after death, and even affinity with the angels. He understands the mystery of God's design and by means of it he understands his elected status in this life and after death. With this in mind, he will be able to understand that the poverty he experiences may include material affliction, but that he also possesses a special inheritance more valuable than all material wealth (cf. Goff 2013:106). Although he will receive the full extent of his elected status only after death, he can already 'walk in it' (line 9) (another traditional word for living righteously), praising God for the special apportionment he received from Him. This allotment enables him to be seated among the nobles (i.e. the angels, cf. Goff 2013:104-105) (line 11).

In the second subunit (4Q416 2 III 12-15) the raz nihyeh is combined with the imperative of דרש (to seek, to study). The study of the mystery enables the learner to know the difference between truth and injustice. Harrington (2001:43) translates line 14-15 as follows: 'Study the mystery that is to be/come and understand all the ways of truth and all the roots of iniquity you shall contemplate'. Although no preposition is used with the term raz nihyeh, it 'has an instrumental sense' (Goff 2013:107-18) in this subunit. By investigating the mystery of existence, the student will know the creation as God has organized it with its dichotomy of good and evil, bitter and sweet, wisdom and folly (cf. lines 14-15). It is the revelation of heavenly knowledge concerning 'all the paths of truth and observe closely all the roots of injustice' (4Q416 2 iii $14 \mathrm{~b})$. This investigation cannot be delayed because the learner experiences the hardship of poverty (lines 12-13). It should be done day by day by strenuously disciplining his thoughts. This is depicted in two metaphorical phrases well known in the Hebrew Bible: stooping the shoulder (הבא שכמכה) and refining the heart (צרוף לבכה). In this way he would understand this inheritance God gave him.

\section{Q416 2 III 15-21}

In this unit the term raz nihyeh is used in 4Q4162 III 15-19 with regard to the learner's relationship with his parents and in 4Q416 2 III 20-21 with regard to his relationship with his spouse. These lines '[paraphrase]and [expand]biblical texts' (Harrington 2001:47). Simultaneously they ${ }^{18}$ '[connect] the implementation of the fifth commandment as well as the marital relationship closely with the mediation on the 'mystery to come' (Elgvin 1997:77).

18.Elgvin (1997:77) refers to this section as " 40416 V $13-21$ '.
4Q416 2 III line 18 reads '....as they uncovered your ear to the mystery that is to be/come, honor them, for the sake of your own honor ...' (Harrington 2001:43-44). As already pointed out, the same Hebrew words found in the fifth commandment (cf. Ex 20: 12 and Dt 5: 16) are used in lines 15 and 16, but now with two additions. In these lines both aesthetic intertextuality ${ }^{19}$ and symptomatic ${ }^{20}$ intertextuality can be found. The command to honour your father and mother is repeated again in line 18. The instruction is linked to the learner's poverty and his inheritance in lines 15 and 19. A harmonious family relationship does not depend upon poverty, but poverty is associated here with the 'humility and modesty' with which he should serve his relations (cf. Goff 2007:59). He is told what it means to be poor with regard to his elect status (cf. Goff 2007:61). This supports the theological theme in 4QInstruction to honour God. The fifth commandment is deconstructed to be part of a larger theological scheme. Just as the father and mother are the source of his existence, God the Creator is the source of his way of living.

When the term raz nihyeh is connected to filial piety in lines 17-18, Goff (2013:113) understands the mystery as having already been revealed and now becomes 'a rationale to practice filial piety'. The study of the mystery brings about knowledge of the created order, the dominion of the Creator God over the creation, and the granted elected status of those to whom this mystery has been revealed through their study of it (cf. Goff 2013:113). The traditional promise of a long life in the fifth commandment now 'alludes to the reward of eternal life after death' (Goff 2013:114).

In 4Q416 2 iii 20-2121 (and the connected 4Q416 2 column iv, cf. Harrington 2001:44) the raz nihyeh is linked to the learner's poverty, ${ }^{22}$ his marriage and his conduct towards his spouse. Numbers 30:6-15 is the probable archi text for these lines. 4Q416 2 III 20-21 reads: 'You have taken a wife in your poverty; take her offspring in your lowly estate [...] from the mystery that is to be/come while you keep company together' (Harrington 2001:44). The revealed mystery teaches the learner to adopt 'a posture of humility and righteousness' (Goff 2013:114) in his married state. According to the divine plan revealed in the mystery, the learner is to remember his elected status and keep in mind that his wife shares this status with him.

\section{$4 Q 4171 \mathrm{i}$}

The fragmentary character ${ }^{23}$ of the manuscripts in 4QInstruction aggravates a contextual reading of this term. Probably the 19. By quoting Exodus 20 .

20.The quotation is not only extended with additional words, but also links filial relationship with the concept of the raz nihyeh.

21.The intertextuality with Genesis 1-3 was indicated above.

22.Cf. the four times repeated reminder that the mebin is poor in column 3 lines 2, 8, 12 , 19. This poverty, whether spiritual or material, reflects 'the human condition and [is] a sign of human limitations [rather] than an ideal to strive for' (Harrington 2001:45) and 'does not seem to be a spiritual ideal (Harrington 2001:46). Goff (2007:55) does not think of poor in economic terms, but rather as 'fixated upon the poverty' of the mebin. They are 'to live in a way that is simple and austere' (Goff
2007:56).

23.Cf. Harrington's remark (2001:46-47) that the 'material is unfortunately fragmentary and obscure, and so it is often hard to be sure of what is being said'. 
'next best preserved part' (Harrington 2001:51) providing some larger literary context to study the use of raz nihyeh is the section of $4 \mathrm{Q} 4171 \mathrm{i}^{24}$

From the two surviving copies in '4Q417 $2 \mathrm{i}$, and the other in 4Q418 43' (Harrington 2001:53) 'a fairly full (if none the less obscure) passage' (Harrington 2001:53) can be reconstructed. Standard wisdom concerns regarding interpersonal relationships and finances are found here. Five occurrences of raz nihyeh can be found in this passage. ${ }^{25}$ In lines 3, 6, 8, 18 and 21 the term is used, each time with the prepositional bet instrumentalis ${ }^{26}$ 'in an instrumental meaning' (Elgvin 2000:235). According to Goff (2013:42), this passage can be divided into four units: lines 1-5, 6-13, 13-18, 18-27.

In unit one (1-5) the raz nihyeh in line 3 indicates 'the means by which knowledge is acquired, through regular contemplation and study' (Goff 2013:143). Goff (2013:138) translates the fragmentary text as follows: '... and gaze [upon the mystery that is to be and the deeds of] old at what exits and what [has existed, upon what will be] ....' Harrington (2001:52) translates lines $3-5$ as: 'and gaze $[\ldots]$ of old to what is, and what is to be in what [...] to what is and what is to be $[\ldots]$ in all [...every] act and act [...]'. The (probable) raz nihyeh ${ }^{27}$ here is to be distinguished from the 'wond[ro]us mysteries' (Goff 2013:138) of line 2. The raz nihyeh is here the instrument that enables the learner to comprehend God's mystery, his power. His divine reign 'extends throughout the entire chronological scope of the created order' (Goff 2003:33). It encompasses 'the entire breadth of history' (Goff 2013:145). History is presented here 'by a tripartite division of time' (Goff 2013:145) 'without systematic elaboration' (Goff 2003:59): past, present and future.

In the second unit (6-13), the 'first large block of fairly legible material' (Harrington 2001:54), the 'vast knowledge' (Goff 2013:142) the raz nihyeh can give is described. Line 6 can be translated as 'By day and by night meditate on the mystery that is to be/come, and study it always' (Harrington 2001:52). By studying the raz nihyeh the mebin can understand 'God's mastery over the created order' (Goff 2013:147). He 'can attain a more profound insight into the nature of reality, in the form of God's deterministic plan that guides history and creation' (Goff 2013:148). According to Goff's reading of lines 8-9 the raz nihyeh entails more than just supernatural revelation by which knowledge can be acquired. God used 'this mystery to create the world' (Goff 2013:151)

\section{What Goff (2013:137 following) names 4Q417 11 , is called Fragment 2 Column (=4Q418 43, 44, 45 i; 4Q418a 11) by García Martínez and Tigchelaar (1997-1998), and $4 Q 4172 \mathrm{i}$ by Harrington (2001:52 following). Cf. also Goff (2013:142) on this issue.}

25.A parallel reading can be found in $4 \mathrm{Q} 41843$

26. Elgvin (1997:80) points out that chokmah is replaced by raz nihyeh in 4 Q417 IX $10-12$ as God's agent in creation. Although terms such as chokmah and 'ormah are used elsewhere as instruments, 'only raz nihyeh is preceded by the instrumental' bet (Elgvin 1997:80, 2000:235). As 'comprehensive word for God's mysterious plan bet (Elgvin 1997:80, 2000:235). As 'comprehensive word for God's mysterious plan
for creation and history' (Elgvin 1997:80) it is the 'plan by which He designed the for creation and history' (Elgvin 1997:80) it is the 'plan by which He designed the
world and its foundations' (Elgvin 2000:235), the blueprint he used to create the world.

27.Cf. Goff's (2013:137) reconstruction of the Hebrew text.
Goff (2013:139) translates lines 8-9 as follows: 'With the mystery that is to be he spread out its foundation and indeed $\mathrm{m}[$ ade (it) with wis]dom and, regarding everything, [with cleve]rness he fashioned it'. Harrington's (2001:52) translation varies from this: '... and its deeds $\mathrm{He}$ has prepared with [...] wisdom, and with all cunning He has fashioned it'. The mystery is both instrument of revelation as well as its contents. One can obtain insight into reality by studying the secret and develop knowledge of the way the creator used this mystery (parallel to ${ }^{28}{ }^{\prime} w i s\left[\mathrm{dom}^{\prime}\right.$ and '[cleve]rness'). This enigmatic dual functionality of raz nihyeh, indicated by the use of the prepositional bet instrumentalis, recalls Proverbs 3:19's statement that God created the world 'with' wisdom..$^{29}$

The term does not occur in the unit of 13-18 with its theme of 'divine judgment on human acts' (Harrington 2001:55), but twice in the unit of 18-27. In this 'poorly preserved' (Goff 2013:168) section an indication is given of what can be learned through the raz nihyeh. The fragmentary text 'seems to be an exhortation to act upon the knowledge that one gains by applying oneself to the "mystery that is to be/come"' (Harrington 2001:56). Goff (2013:140) translates lines 18-19 as: 'And you, understanding son, gaze ... vacat ... upon the mystery that is to be and know [the path]s of all life ....' Line 21's translation does not make much sense: '... your ... in the mystery that is to be ...' (Goff 2013:140). This section deals with supernatural revelation and the elected status of the mebin. It takes up once more the theme of lines 11-12 of God's disclosed deterministic plan for the world and the learner's duty to act (i.e. walk) in accordance with it.

\section{Summary}

In both 4Q416 2 III 15-21 and 4Q417 1 i the raz nihyeh has two functions. First, it is an entity to be studied. Secondly, it is the medium through which one is enabled to understand the world in which one lives. Within the context of wisdom teaching the mebin's (learner's) study of the raz nihyeh educates him as to who he is and what he should do.

By strenuously disciplining his thoughts and meditating upon the mystery day and night, he will understand that he has an elected status. Using traditional wisdom phrases he is taught by studying the mystery that he possesses a glorious inheritance, $^{30}$ a distinct station in life. Although he is materially poor, this inheritance supersedes all earthly wealth. This asset enables him to live an ethically distinguished life. Not only his filial and matrimonial relationships are

28.According to Kampen (2011:loc. 679), the term 'wisdom' in Proverbs is used differently in 4 QInstruction. Here 'the largest number of references point to mysteries and hidden wisdom, a connection not apparent in the biblical book' (Kampen 2011:loc. 679).

29.Goff (2007) points out the interrelationship of Proverbs 8, Ben Sira 24 and Wisdom of Solomon with Lady Wisdom in 4Q185. Although several of the central ideas in Proverbs and Sira regarding Lady Wisdom are omitted in 4Q185, the allusion of wisdom here to the other two texts is 'an intriguing possibility that can be left open' (Goff 2007:135). The embrace of wisdom depicted in 4Q185 in humanlike form is not intended to be erotic but rather to portray the "honesty and integrity of one's devotion' (Goff 2007:138).

30.Cf. Goff (2013:101-102) for a discussion of this word. 
different, but everything he is taught in 4QInstruction forms him into a different type of person.

Contemplating and studying the raz nihyeh he learns to understand God's power and his mysterious rule, his mastery of the creation. The mystery 'is the central means of acquiring wisdom, or the ability to understand the world' (Goff 2014:221). The raz nihyeh reveals to him the 'full extent of God's dominion over history and creation, manifested as a deterministic plan that orchestrates events' (Goff 2007:67). It shows him how to live and to distinguish between wisdom and foolishness, good and evil.

He becomes part of 'God's divine plan guiding reality' (Goff 2013:102) that promises to him eternal life after death. Not only the past and present, but also the future as part of this deterministic plan.

God used the raz nihyeh to create the world. But it is still functioning as revelatory agent to reveal not only the instrumentality of the mystery during the creation, but also the present and future role it plays in God's deterministic rule of the earth.

\section{Lady wisdom in Proverbs 1-9 Proverbs 8:1-36}

In this 'character sketch of wisdom' (Brown 1996:loc. 412) wisdom is depicted as a person in Proverbs ${ }^{31}$ 1:20-33, 8:1-36, ${ }^{32}$ and 9:1-6. In the 'Wisdom speech' (Murphy 1998:49) in 8:1-36 an encomium is found of wisdom 'in terms of its paramount status, evidenced by the ordering of the world, all of which functions as a strong incentive to acquire wisdom' (Loader 2014:367). Although this 'extended exordium' (Fox 2008:292) focuses on personified wisdom, ${ }^{33}$ it is mainly an instructive strategy to present 'fundamental sapiential instruction by means of credible substantiation' (Loader 2014:367). ${ }^{34}$ It is a 'mythological way to teach the wisdom of Proverbs' (Goff 2003:43). The way wisdom is depicted in this pedagogical teaching, however, 'conveys an unusual conception of wisdom and makes powerful claims for this entity' (Fox 2008:292).

31.Only fragments of Proverbs (40102-113) have been found at Qumran (cf. Harrington 2001:3). 4Q102 contains parts from Proverbs $1: 27-2: 1$ and $4 Q 103$
'remnants of Proverbs $14: 31-15: 8$ and $15: 19 b-31$ in two columns, as well as remnants of Proverbs $14: 31-15: 8$ and $15: 19 b-31$ in two columns, as well as
fragments of 13:6b-9b; 14:6-10; and 14:12b, 13b' (Harrington 2001:15-16). fragments of $13: 6 b-9 b ; 14: 6-10 ;$ and $14: 12 b$ of
Nothing of Proverbs 8 has been found there.

32.Chapter 8 is investigated here because it is more extensive in depicting wisdom's character than 1:20-33 and 9:1-6. Yee (1982:58) studies Proverbs 8:22-31 as a separate study 'on the basis of its distinct content and language'.

33.Too much has been made of the personification of wisdom in the past. This was probably done because the Nachgeschichte of the poem was linked to Christ. The purpose should rather be to read the personification in line with the parental education in the rest of Proverbs 1-9. Murphy (1998:48) refers to human experience as the common denominator between chapter 8 and the rest of Proverbs 1-9, giving to this chapter 'its proper place within the book of Proverbs'. Fox (1997:618-619) sees this personification as a 'conduit of wisdom' that the author uses a persona to communicate his message. Elsewhere in Proverbs 1-9 the author uses a persona to communicate his message. Elsewhere in Proverbs 1-9 the infuse 'in the readers not only knowledge but attitudes and perspectives that will guide their behavior' (Fox 1997:619).

34.In opposition to this, Fox (2008:293) says the 'object of attention is not the father's teachings but wisdom generally'. Murphy (1998:49) points out that wisdom takes up the role of the parent in 8:32-36, 'but she remains speaking until the end'.
Fox (2008:292) calls 8: 1-36 'Interlude ${ }^{35} \mathrm{D}^{\prime}$. He divides this 'neatly structured' (Fox 2008:292) poem into three sections ${ }^{36}$ : an introduction in 8:1-3, wisdom's address in 8:4-31 (further subdivided into 4-11, 12-21, and 22-31); and the conclusion of the oratory in 8:32-36. Loader (2014:321) identifies a 'concentric pattern of chiasmus' and divides the 'long poem on wisdom's inner character' into four sections. The first $(8: 1-11)$ and last (8:32-36) sections form an outer circle and refer to the interrelatedness of wisdom and mankind. The sections of 8:12-21 and 8:22-31 form an inner circle describing wisdom's relation to the world (cf. Loader 2014:321).

Both Fox and Loader agree on parsing 8:12-21 and 8:22-31 as subunits of 8:1-36 (8:12-21 as subunit of 8:4-31 in Fox's case). Whereas Fox (2008:292) interprets both units in terms of chronology (Wisdom's present state in 12-21 and her past in 22-31), Loader (2014:321) reads it in terms of a relationship between wisdom and the present world (12-21) and the primeval world (22-31). Loader's larger context is preferable as both sections rather deal with relationships and especially wisdom's function in a universal context.

\section{Proverbs 8:22-31}

This section 'throws into relief the meditative role of Wisdom between humankind and God' (Yee 1982:60). It depicts 'Wisdom as the ultimate mediator between God and humanity' (Yee 1982:66). However, the 'character of this mediation is not specified' (Yee 1982:60). According to Murphy (1998:52), the relationship between Woman Wisdom and the Lord is described in 'a mysterious way' in 8:22-31. In Loader's (2014:345) opinion, wisdom's origin is described in 8:22-23 'with enough clarity and vagueness so as to bring about more of a suggestive reference to Wisdom's origin than a clear description' (my underlining of 'and'). Although Wisdom focuses on humans, she has 'a divine provenance' (Goff 2003:44) that gives her an esoteric character.

In 8:22-31 wisdom's speech enters the cosmic area. Present already at the creation of the world, standing in primordial relation to God, she enounces that she stands in closest relationship to those who attend to her words. She enables them to experience God's creation in all its splendour.

Fox (2008:292) divides 8:22-31 into three subsections ${ }^{37}$ dealing with wisdom's priority in terms of the creation of the world (8:22-26), her presence during creation (8:27-29) and being 'God's darling and mankind hers (30-31)' (Fox 2008:292). Loader (2014:433) calls 8: 22-31 the 'Second Speech Core' that corroborates Wisdom's claims in the previous 'core section' in 8:12-21 (cf. Loader 2014:292).

\footnotetext{
35.Loader (2014:318) does not see this chapter as an interlude, 'a pause in the midst of an ongoing composition'.

36.Yee (1982:58) sees it as 'a tripartite poem' and divides it into 8:1-22, 8:12-21 and 8:22-31, with 8:32-36 as an epilogue.

37.Yee (1982:61) also uses a 'threepart structure', and divides it into three strophes: $8: 22-26,8: 27-30 a, 8: 30 b-31$.
} 
The subsection of 8:22-26 deals with three entities: Yahweh, wisdom and the world (cf. Yee 1982:60). The Lord himself created both wisdom and the world. However, although both are equally creations of God, wisdom has chronological as well as status priority. The intention of the poet 'was to show that wisdom transcends time' (Terrien 1981:134). Wisdom was created in a time when the earth with its waters and land had not yet been created. This 'primordial creation' (Loader 2014:350) of wisdom not only means that she was first in time, but also 'implies superiority and excellence' (Loader 2014:350).

Loader (2014:349) compares the way wisdom is depicted in chapter 8 with that of chapter $3^{38}$. While wisdom is 'an aspect of the divine being' (Loader 2014:349) in 3:19, it is a creation (in 8:22) right at the beginning when there was only a chaotic and formless primeval ocean. As will become clear in 8:30-31, she is not presented here as a 'mediatrix through which other things were created' (Loader 2014:349), a 'co-creator' (Loader 2014:361). She is not the source of the rest of the creation.

The topic of 8:27-29 is wisdom's presence during God's creation of the world (cf. Fox 2008:281-282; Loader 2014:354). A shift takes place from the "before" clauses in vv 24-26 to "when" clauses in vv 27-29' (Fox 2008:281). Six creative actions are described in 8: 27-29, all 'in "when" clauses subordinate to Wisdom's statement, "there was I"' (Fox 2008:282). According to Murphy (1998:55), it is not the depiction of creation that is important here, but rather the ${ }^{39}$ pre-existence of wisdom. Brown (1996:loc 426) says that here the use of the 'cosmogonic language is to focus not so much on the process of creation as on wisdom's position in relation to creation and God'. The phrase in 8:27 there was I (Hebrew sjam ani) refers to a situation, not a localisation (cf. Fox 2008:284). Whereas 8:22-26 deals with situation of not-yet, 8:27-29 deals with God's creative action. In all of this wisdom is an observant bystander noticing God's division of the cosmos into three sections of heaven above, waters and land underneath and waters under the earth.

The climax of 8:22-31 is found in 8:30-31, 'where her relationship to God and to human beings is affirmed' (Murphy 1998:55). Wisdom exists in relationship to both God and man. She acts independently, neither being an agent in God's creative activity, nor being equal to the rest of the creation, but superior to them all. There is 'a decided aesthetic dimension' (Loader 2014:361) that she brings to God and the world. When God created the world she was beside him 'growing up in his care and giving him delight' (Fox 2008:285). She was like a 'nurseling' or 'foster child' (Loader 2014:360), 'a little girl playing around on the building site' (Loader 2014:359). She 'imbues the workshop of her Father with joy so that he himself also has part in it' (Loader 2014:362).$^{40}$ Wisdom's speech finds its 'climax in the phenomenon of joy' (Brown 1996:loc. 432). She 'provides joy by being joyful and playful' (Loader 2014:360) and 'not only provides God pleasure but she herself also derives pleasure from human beings herself' (Loader 2014:360).

38.Loader (2014:322) refers to Whybray's description of $8: 1-36$ as baroque development' of 3:19.

39.Brown (1996:loc 426) refers to 'wisdom's primordial, albeit non-pre-existent, nature'.

40.Terrien (1981:134) indicates that the theme of sapientia ludens ('the play of wisdom') is a theme not found in the literature of Israel before.

\section{Proverbs 8:12-21}

In 8:12-21 'wisdom's discourse turns from the topic of speech to character' (Brown 1996:loc. 415). Here wisdom claims to be all-important in the world of mankind. Wisdom introduces herself in 8:12-13 in terms of her continuing 'prowess and prestige' (Fox 2008:279). Fox (2008:271) remarks here that wisdom is not identical to cunning, but rather 'has an abiding connection to it ... not precisely equated with it'. She is the medium through whom these qualities are bestowed on those who identify with her. Brown (1996:loc. 415) remarks that 'the language seems more appropriated to the recipient of wisdom rather than to wisdom herself'. Wisdom is the embodiment of the 'ideal character of her inquirer' (Brown 1996:loc. 421). She 'embraces all aspects of human life' (Crawford 1998:357).

The instrumentality of wisdom is described in the two synonymous parallel subunits of 8:14-16 and 8:17-21.

In the first subunit (8:14-16) '[w]isdom commends herself as the fount of statecraft, thus of ordered society itself' (Fox 2008:271). Wisdom is in possession of counsel, cleverness, and strength (cf. Loader 2014:337). She is the channel through whom these qualities can be obtained by all who rule (cf. the use of the bet instrumentalis in verses 15 and 16).

The subunit of 8:17-21 is in the form of a ring composition: it starts and ends with those who love wisdom (Hebrew 'ohebay'). Wisdom's 'Material Benefits' (Fox 2008:275), depicted as 'cleverness, power, dominion, and wealth' (Fox 2008:278), are conferred upon those who identify with wisdom. In this reciprocal relationship there is a close association between material and ethical concepts, even if the material benefits are the prominent ones' (Loader 2014:340).

\section{Summary}

Terrien (1981:137) summarises this section as the 'call to ethical obedience ... integrally articulated upon a feminine personification of wisdom, mediatrix of communion with the transcendent Creator'. Wisdom is personified in Proverbs 8:1-36 acting like a human, but not being human at all. ${ }^{41}$ This depiction of wisdom is a didactic strategy to promote following wisdom in one's life.

The call to wisdom in Proverbs 8:1-11 and 8:32-36 is substantiated by the description of its relation to the contemporary world $(8: 12-21)$ and the primordial creation (8:22-31).

In 8:22-31 wisdom is depicted mysteriously as both being lucid and simultaneously obscure. 'She is a strange being, a personification of mental power' (Fox 1997:624). She is 'a mystery ... an enigma to scholarly research' (Lang 1986:113),

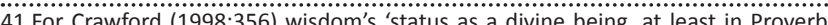
$1-9$, seem[s] unquestionable'. She relates wisdom's attributes and actions to Ancient Near Eastern tutelary gods' (Crawford 1998:356 note 2). Lang (1986:51Ancient Near Eastern tutelary gods' (Crawford 1998:356 note 2). Lang (1986:51-
81 ) sees wisdom in Proverbs 8 as a 'Goddess'. Being created by God makes both of 81) sees wisdom in Prover
these opinions doubtful. 
'a fairly vague figure' (Lang 1986:147). She is a pre-existent creation of God, already present at the creation of the world, not only being very old but also superior to anything else. ${ }^{42}$ 'She transcends mundane reality and human minds' (Fox 1997:624). She was not used by God as an agent to create the world (cf. Fox 1997:628), but was present at the creation giving him delight in what he did. She was not involved in directing 'the course of events' (Fox 1997:629). Rather than doing anything specifically, she played her role by being present for God and man. Standing in a reciprocal relationship to God and mankind she was giving joy to all of them.

In 8:12-21 she is instrumental in giving humans possession of 'cleverness, power, dominion, and wealth' (Fox 2008:278). Whoever stands in a relationship with wisdom is endowed with material benefits leading an outstanding ethical life. Her invitation is extended to all human beings. She 'symbolizes the perfect and transcendent universal' (Fox 1997:630). She is a-temporal and although she operates within the spatial realm, she also belongs to the supernal realm.

\section{The larger context}

Although the wisdom terminology and the use of wisdom as a category indicate some common ground between the two documents, the aspect of a changing worldview seems to be the central issue. According to Kampen (2011:loc. 484), it is 'the worldview advocated in the text rather than a female figure' that differentiates between Proverbs and 4QInstruction.

Wisdom 'constitutes a particular understanding of reality' (Collins 1997:266). In Proverbs the creation has 'an inherent structure and natural order' (Goff 2014:221). In Proverbs 3:19 and 8:1-36 this is associated with personified wisdom.

4QInstruction stands in 'marked contrast to the semiautonomous and even personified portrayal of wisdom advanced in Proverbs' (Kampen 2011:loc.484). There is no hint there of any personification of wisdom. The Qumran texts 'arose in a society and culture in which the ideas and literary forms of wisdom writings were well known' (Harrington 2001:4). 4QInstruction does include instructions on sapiential subject-matter such as matrimony, parental obedience and repaying debts punctually. However, apocalyptic ideas ${ }^{43}$ began to influence the sapiential discourse

42. Fox (1997:624) refers to the different hypotheses used in research to explain the depiction of Lady Wisdom: 'human and divine, real and mythological.' Although no single source can be indicated as the model used for this depiction, Fox (1997:625) finds the portrayal of the teacher as the one who 'provides the grid which holds together the component features'.

43.Both Von Rad during his life and Lange (1995), who followed him during the 1990s, were of the opinion that wisdom is the ultimate source of apocalypticism. It is clear that wisdom was reflected upon (as found in Ecclesiastes) in a social context in which apocalyptic ideas played only a part. Lockett (2005:148) makes an importan remark with regard to the book of James in the New Testament that can be applied to the debate of wisdom rising from apocalyptic literature or vice versa: 'we must to the debate of wisdom rising from apocalyptic literature or vice versa: 'we must think of a continuous spectrum, a sliding scale, in which elements of traditional wisdom and eschatological world-views are intermingling'. For Burkes (2002:44) the Wisdom of Solomon signifies a time when wisdom literature developed a new dimension suggesting a 'transformative moment in the religious and philosophica cultural discussion' where older literary types like wisdom were 'pressed into service' by using apocalyptic forms 'to express evolving worldviews in a search for credible methods of cultural self-preservation'. since the second century B.C.E. ${ }^{44} 4$ QInstruction (represented in 1Q26, 4Q415-418 and 423) has a different frame of reference from biblical wisdom (cf. Collins 1997:272). Although various wisdom themes, also found in older material (cf. Collins 1997:272; cf. also page 278), are addressed in 4QInstruction, the ethics proposed here 'are grounded in a comprehensive view of the purpose of creation, summed up in the enigmatic phrase raz nihyeh ...' (Collins 1997:272). Other views from elsewhere in the Ancient Near East could have influenced this comprehensive view. In this case the phrase raz nihyeh bears a 'strong eschatological perspective' (Collins 1997:274). The way the world is understood bifurcates from Proverbs and stands in 'continuity with the apocalyptic tradition' (Goff 2014:220). In 4QInstruction an eschatological orientation is found 'that is conspicuously lacking in older Hebrew wisdom' (Collins 1997:276). It even departs 'radically' (Collins 1997:278) from the existing wisdom tradition. The raz nihyeh implies reward and retribution after death - an idea not found in the older material. ${ }^{45}$ Although 4QInstruction falls within the 'typical wisdom genre', it 'has an eschatological perspective ${ }^{46}$ which we associate with apocalypticism rather than with traditional Hebrew wisdom' (Collins 1997:279).

Proverbs 8 shares some formal components with 4Q416 2 III 15-21 and 4Q417 1 i. In both Proverbs and 4QInstruction the language of cognition and education is used. Both have as their object 'character formation, through ethical advice and the development of an accurate understanding of the world' (Goff 2007:287).

A central idea found in both Proverbs and 4QInstruction is that there is an object that plays a central role in life. Call it factor $X$, if you will. It has an identical function in both. It encompasses everything of God's integrated creation and simultaneously serves as a revealing agent through whom or through which that comprehensive creation can be known and experienced. Both are 'associated with the rational structure of the world' (Goff 2007:291).

In both cases learners are encouraged to dedicate their time and energy to study this factor X. In both the person's ethical conduct is dictated by the contents of this mysterious figure. It sets the parameters of all activities and thoughts of the learner.

44.Goff (2007:296) says that wisdom and apocalypticism were not two totally separated 'streams of tradition', but parallel traditions 'each with its own origins separated 'streams of thadition', but pand and 'process of 2003:65). During influences' (Goff 2003.65). During the late Second Temple period of time the boundaries between them became 'quite nebulous' (Goff 2007:296). A 'cultura theodicy' (Goff 2007:297) occurred where it became important to understand God's control 'in terms of revelation and determinism' (Goff 2007:298).

45.Referring to the way traditional material was differently interpreted in books such as Ben Sira, 1 Enoch, Wisdom of Solomon and 4QInstruction, Goff (2007:145) labels 4QInstruction as 'another stream of the sapiential tradition, transformed by influence from the apocalyptic tradition'. Along with other Qumran sapiential texts, it renders 'an impression of the variety of Jewish wisdom during the late Second Temple period' (Goff 2007:308).

46.Elgvin (1998:129) remarks that 4 QInstruction does not have the developed dualism of the Two-Spirit Treatise in 1QS 3-4 and the War Scroll'. It is not an cher. Theatise in 1QS $3-4$ and the War Scroll. It is not an it does not use a narrative form. However, some apocalyptic motifs are found, but not any deterministic scheme of history divided into periods. World and man are not any deterministic scheme of history divided into periods. World and man are
understood more in apocalyptic terms than in traditional wisdom terms (cf. Elgvin 1998:131, 2000:238-239). 
Both wisdom and the secret-to-be are mystifying. The raz nihyeh is literally called a 'secret', a puzzle. The wisdom is both transparent and simultaneously somewhat of a mystery, being superior to mankind. She is a mythological type of figure marked by 'clarity and vagueness' (Loader 2014:345).

In Proverbs 8 as well as 4QInstruction the object to be studied plays an intermediary role. In 4QInstruction the raz nihyeh is the key to understanding God's governance of His creation and his place in God's deterministic rule of history. The person who studies the raz nihyeh understands the plan of salvation, the eschatological secrets and the glorious inheritance of the elected. In Proverbs the personified wisdom stands in an intimate relationship to those who follow her and endows them with material wealth in the orderly world God created.

When it comes to depicting this figure closer, the contemporary worldview plays the main role. In Proverbs it is presented as a lady who should be studied and even embraced. Although she performs in an anthropomorphic form, she is not human at all. She is neither a divine being nor a hypostasis of God. She is rather a personified idea, primordial old, created before everyone and everything, superior to all of them, in a privileged position to bring joy to God and man. She contributes something to man and the world that is not an inherent part of either.

Although some texts from Qumran show knowledge of wisdom as a lady, they 'contain virtually no portrait of Lady Wisdom' (Goff 2007:290). While personified wisdom plays a central role in Proverbs 1-9, Ben Sira and the Wisdom of Solomon, it is rather the raz nihyeh that takes central stage in 4QInstruction. Hypostatic wisdom is never linked to creation in $4 \mathrm{QInstruction}$. It is rather replaced by the impersonal raz nihyeh to fulfil the same function. Referring to 4Q417 1 i lines 1-13, Elgvin (2000:235) remarks that raz nihyeh here 'is clearly a reinterpretation of the divine Wisdom of Proverbs 1-9'. It 'represents an apocalyptic reinterpretation ${ }^{47}$ of the concept of divine Wisdom that stresses the esoteric nature of God's revelation' (Elgvin 2000:237).

Both Proverbs 8 and the texts of 4QInstruction investigated above work with a cosmic context. Proverbs has a static worldview and the Instructions a dynamic one. Proverbs depicts a primordial tripartite world of heaven, earth and waters in which wisdom plays an enriching role. In Proverbs wisdom is 'an innate mental aptitude that leads to success and fulfilment in this world' (Goff 2007:292). Wisdom teaches one how to live here and now. Wisdom in Proverbs 8 enlightens the learner to understand the world he lives in, in terms of the primordial past of its creation and the joy wisdom brings to the creation at present.

47.This, of course, has to be qualified by explaining in which way the raz nihyeh is an apocalyptic redevivus of personified wisdom.
While Proverbs sees the world in terms of past and iterative present, the scope in $4 \mathrm{QInstruction}$ is enlarged also to include the future. 4QInstruction's comprehension of the world departs radically from the creation theology of Proverbs (cf. Goff 2007:294). 4QInstruction presents creation 'as a mystery that is disclosed to the addressee' (Goff 2003:65); its world has a chronological extension of past and present into the future. In 4 QInstruction the raz nihyeh gives the mebin who studies it eschatological cognition of his future. As in Proverbs, the mystery corroborates a stable existence, but places it in the context of the future. All of history is guided by God's settled plan for his creation that includes past, present and future. The raz nihyeh provides the learner with the knowledge of 'the comprehensive plan that orchestrates history and creation' (Goff 2007:293). The raz nihyeh is a revelation of the deterministic order of the world. The mebin of $4 \mathrm{QInstruction}$ possesses a glorious inheritance that would bring to him eternal life among the angels. The mebin should keep this larger context in mind in his daily life. The raz nihyeh 'affects the addressee's ethical conduct and the way he handles his daily affairs' (Goff 2003:73). Although no chronological scheme is used (yet), the future and its influence on present life form the focus in 4QInstructions.

The addressees differ radically from each other. A change takes place from an all-inclusive view to an exclusive view. In Proverbs 8 wisdom addresses all mankind, including even those who are simple and foolish (cf. Pr. 8:4-5). Those who embrace wisdom are promised material wealth and prosperity. In $4 \mathrm{QInstruction,} \mathrm{on} \mathrm{the} \mathrm{other} \mathrm{hand,} \mathrm{'genuine}$ wisdom requires supernatural revelation available only to the elected'48 (Goff 2014:220). The mebin in 4QInstruction enjoys an elected status, although he may be materially poor at present. This exclusiveness might even have contributed to the idea that ethereal wisdom restricted to a few is something privileged, a secret known only to those elected. But it is a revealed secret for the mebin that guides him through life.

It seems that Lady Wisdom survived a time of increasing apocalyptic influence when a confluence of wisdom and apocalypse occurred. She was de-feminised and mystified in a time of increasing intertextual activity when an immense increase in the production of literature took place.

\section{Acknowledgements}

Assistance from the National Research Foundation is hereby acknowledged.

\section{Competing interests}

The author declares that he has no financial or personal relationships which may have inappropriately influenced him in writing this article.

48.Elgvin (1998:117) is of the opinion that 'regular society' is intended here, although 'related to some kind of community'. They had a specific way of interpreting scriptures 'and God's mysteries' (Elgvin 1998:117). Goff (2007:54) refers to 'a humble and austere social setting'. 


\section{References}

Brown, W.P., 1996, Character in crisis: A fresh approach to the wisdom literature of the Old Testament, Eerdmans, Grand Rapids, MI. (Kindle ed.).

Burkes, S., 2002, 'Wisdom and apocalypticism in the Wisdom of Solomon', The Harvard Theological Review 95(1), 21-44.

Claes, P., 1987, 'Bijzondere en algemene inertextualiteitstheorie', Spiegel der Letteren 29, 7-15. http://dx.doi.org/10.2143/SDL.29.1.2014501

Collins, J.J., 1997, 'Wisdom reconsidered, in light of the Scrolls', Dead Sea Discoveries 4(3), 265-281, http://dx.doi.org/10.1163/156851797X00137

Crawford, S.W., 1998, 'Lady Wisdom and Dame Folly at Qumran', Faculty Publications, Classics and Religious Studies Department, Paper 23, viewed 29 June 2016 from http://digitalcommons.unl.edu/classicsfacpub/Published 09/1998

Elgvin, T., 1997, 'An analysis of 4QInstruction', Doctor of Philosophy Thesis, Hebrew University of Jerusalem.

Elgvin, T., 1998, 'The mystery to come: Early Essene theology of revelation', in F.H. Cryer \& T.L. Thompson (eds.), Qumran between the Old and the New Testaments, Journal for the Study of the Old Testament. Supplement Series 290, pp. 113-144, Sheffield Academic Press, Sheffield.

Elgvin. T., 2000, 'Wisdom and apocalypticism in the early second century B.C.E. - The evidence of 4 QInstrution', in L.H. Shiffman, E. Tov \& J.C. Vanderkam (eds.), The dead sea scrolls. Fifty years after their discovery, Proceedings from the Jerusalem Congress, Israel Exploration Society, Jerusalem, 20-25 July 1997, pp. 226-247.

Fox, M.V., 1997, 'Ideas of Wisdom in Proverbs 1-9', Journal of Biblical Literature 116(4), 613-633. http://dx.doi.org/10.2307/3266550

Fox, M.V., 2008, Proverbs 1-9: A new translation with introduction and commentary, Vol. 18A, Yale University Press, New Haven, London.

García Martínez, F. \& Tigchelaar, E.J.C., (1997-1998), The Dead Sea Scrolls Study Edition (translations), Brill, Leiden, New York.

Goff, M.J., 2003, The worldly and heavenly wisdom of 4QInstruction, Brill, Leiden.
Goff, M.J., 2007, Discerning wisdom. The sapiential literature of the dead sea scrolls, Brill, Leiden.

Goff, M.J., 2013, 4QInstruction, wisdom iterature from the ancient world, Society of Biblical Literature, Atlanta, GA

Goff, M.J., 2014, 'Wisdom, apocalypticism and intertextuality: The Book of Ecclesiastes and the sociolect of the Dead Sea Scrolls', in K. Dell \& W. Kynes (eds.), Reading ecclesiastes intertextually, pp. 215-226, T. \& T. Clark, London.

Harrington, D.J., 2001, Wisdom texts from Qumran, Taylor \& Francis e-Library, Oxfordshire.

Kampen, J., 2011, Wisdom literature, Eerdmans, Grand Rapids, MI.

Lang, B., 1986, Wisdom and the book of Proverbs. A Hebrew goddess redefined, The Pilgrim Press, New York.

Lange, A., 1995. Weisheit und Prädestination: Weisheitliche Urordnung und Prädestination in den Textfunden von Qumran. Studies on the Text of the Desert of Judah 18, Brill, Leiden. Date (1995) added to footnote 44.

Loader, J.A., 2014, Proverbs 1-9. Historical Commentary on the Old Testament, Peeters, Leuven.

Lockett, D., 2005, 'The spectrum of wisdom and eschatology in the epistle of James and 4QInstruction', Tynndale Bulletin 56(1), 131-148.

Murphy, R.E., 1998, Proverbs, Vol. 22, Word, Incorporated, Dallas, TX.

Nickelsburg, G.W.E., 2001, 1 Enoch 1, Fortress Press, Minneapolis, MN.

Nickelsburg, G.W.E., 2005, Jewish literature between the Bible and the Mishnah: A literary and historical introduction, 2nd edn., Fortress Press, Minneapolis, MN.

Schmitz, P.F., 1987, 'Intertextualiteit door signalen en door symptomen', Spiegel der Letteren 29, 25-32. http://dx.doi.org/10.2143/SDL.29.1.2014503

Terrien, S., 1981, 'The play of Wisdom: Turning point in biblical theology', Horizons in Biblical Theology 3, 125-153. http://dx.doi.org/10.1163/187122081X00064

Yee, G.A., 1982, 'An analysis of Prov. 8 22-31 according to style and structure', Zeitschrift für die Alttestamentliche Wissenschaft, 58-66. http://dx.doi. org/10.1515/zatw.1982.94.1.58 